НАТАЛІЯ БІДАСЮК, кандидат фбілологічних наук, доцент НАТАЛІЯ СОБОЛЬ, кандидат педагогічних наук, доцент (л. Хлельницький)

\title{
Американський футбол як культурна і мовна метафора
}

У статті розкрито суть поняття "алериканський фбутбол»та його летафборичного вживання у сучасній літературі у якості синоніла до слова "алериканець". На конкретних прикладах 3 художньої літератури, текстів пісень, газетних статей показано поповнення лексичного складу англійської мови іншили метафоризованили бутбольнили терлінали. Акиентовано увагу на толу, що алериканський фбутбол - один із важливих складників алериканської ідентичності, як культурної, так $i$ мовної.

Ключові слова: алериканський ббутбол, летафора, ідентичність, квотербек, неологізл.

Постановка проблеми в загальнолу вигляді... Американський фрутбол є невід'ємною частиною життя американців. Вивчаючи його, можна дізнатися про їхню ментальність та особливості уявлень про світ. Ця гра стала джерелом утворення безлічі неологізмів, у тому числі ідіоматичних виразів, у мові та основою для художніх образів у літературі.

Аналіз досліджень $i$ публікацій... Метафору «американський фрутбол» досліджували як зарубіжні, так і вітчизняні учені. Профресор Каліфорнійського університету Мартін Ганнон присвятив цьому різновиду футболу один із розділів своеї монографії, у якій пропонуе використовувати культурну метафору як метод/ карту для вивчення ментальності націй [6]. Вербицька О. Ю. розглядае аксіологічну та національно-культурну специфіку об’ективації цінностей сучасного американського суспільства через поняття американського футболу [1]. Дослідниця виділяе п'ять основних категорій, важливих для американців, які можна описати за допомогою метафори американського футболу: індивідуалізм, рівність, матеріалізм, робота і 
дозвілля, конкуренція. А. Алхімовіч аналізуе бізнес середовище інформаційних технологій через призму фрутболу 3 акцентом на командній роботі. Явище ціеї спортивної гри розкладаеться на чотири складових: команда, зірковий гравець, глядачі та місце події [4]. Ж. А. Терпелець займається проблемою підвищення ефективності мовної комунікації у фрутбольному середовищі 3 огляду на етнокультурні особливості гри у різних країнах [3]. К. Пол порівнюе роботу квотербека та редактора, а футбольне поле 3 написаною сторінкою [10]. Американський спортивний дискурс, його терміносистема, а також вживання спортивних термінів (з хокею, бейсболу, американського футболу та баскетболу) у різних видах засобів масової інформації та у побуті вивчае Д. Е. Дмитрошкін [2]. На часі стоїть дослідження, які би деталізували внесок американського футболу в збагачення лексичного складу англійської мови та їі образність.

Форлулювання иілей статmі... Метою нашої розвідки є вивчення особливостей метафори американського футболу та інших прикладів фрутбольної термінології у текстах різних жанрів: художніх, газетних. Ми ставимо перед собою завдання розкрити значення цієї культурної

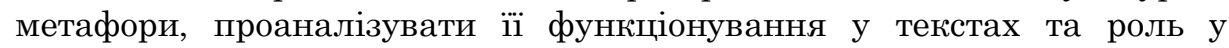
збагаченні словникового запасу англійської мови.

Виклад основного матеріалу... М. Іаннон висловив кілька тверджень у своїй науковій праці, які одразу стали відомими цитатами: «Якщо ви не розумієте американський фрутбол, то вам буде складно зрозуміти американську культуру i те, як вести бізнес у США», «Недільний фрутбол витіснив Різдво з місця національного свята, на якому збираються друзі та родичі» [6, с. 206]. Якими б суперечливими не здавалися ці слова, але вони свідчать про те, що американський футбол - одна з ключових культурних метафор, яка стала синонімом США. Найближчим спортивним конкурентом може бути тільки бейсбол. Але якщо бейсбол - це романтика, простір, які швидше стосуються минулого країни, то американський футбол - це динамізм, напад і захист, чоловіча солідарність та індивідуалізм, вищість закону. Це характеристики, які описують сучасну американську ідентичність [5].

Любити американський фрутбол = бути американцем. Саме цю формулу використовують деякі письменники для підкреслення «американськості» своїх персонажів. Наприклад, Субхаш, іммігрант 3 Калькутти у романі Джумпи Лагірі «Низовина», відчув себе не чорноробочим, а вільним громадянином, коли усвідомив, що схожий на інших американців: «Після обіду він сідав у машину та їхав, куди 
заманеться. Він їхав у Джеймстаун через міст, до Ньюпорта і назад. Слухав по радіо попсу, прогноз погоди для тих, хто на суші і на морі», а ввечері «він сідав за барну стійку, пив пиво, багато їв, дивився по телевізору американський футбол» [8, с. 44].

Б.Мухерджі накладае американський фрутбол на бенгальську традиційність іммігрантів у своему романі «Бажані доньки» [9]. Два хлопці, Біш та Чет Йі, створюють електронну систему «СНАТТЕЕ», коли дивляться гру Джона Монтани по телевізору. Вони хапаються за ідею "нападу по-західному» - короткі влучні передачі, які використовують ширину поля, а не довжину. Вони створили аналогічну програму для передачі інформації на короткі відстані у напрямках, де $е$ вільні отримувачі, таким чином пришвидшуючи процес безперешкодного обміну даними. У творі події переносяться 3 небезпечного Бомбею до таємничого індійського села Міштігундж, 3 недормального Сан-Франциско до світських індійських вечірок у НьюДжерсі та вишуканих індійських бутиків у Нью-Йорку. У такий спосіб оповідачка поєднуе різні країни, культури i покоління, минуле i теперішне. Можна говорити про те, що роман теж використовуе естетику ширини поля, піднімаючи теми історії, географріï, діаспори, етнічності, мови, гендеру, а не застарілу форму лінійної оповіді, яку можна порівняти 3 довгим кидком у довжину в бейсболі.

Футбол є втіленням багатьох американських цінностей та практик. Американський фрутбол має у своєму арсеналі унікальне правило: гравці збираються на нараду в центрі поля перед розіграшом м'яча. Вони можуть обговорити стратегію, висловити підтримку чи зауваження, наголосити на мотивації - усе для досягнення своєї мети. M. Ганнон провів вдалу паралель між цими нарадами (huddles) та поведінкою пересічних американців: «Ці американці - найдивніші люди у світі. Ви не повірите, якщо я розповім вам, що вони роблять. Припустимо, у місцевій громаді один мешканець має якусь незадоволену потребу. Що він робить? Він переходить через дорогу, щоб обговорити іï з сусідом. Що далі? Створюється комітет, який починає підтримувати висловлену пропозицію... I це все без жодного натяку на бюрократію. Все роблять приватні громадяни зі своеї власної ініціативи» [6, с. 213].

Популярність гри накладае відбиток i на мову. Культова американська гра дала ряд неологізмів, утворених, в основному, на основі метафоризації. «Quarterback» (розігруючий квотербек) означає позицію гравця, який розташовуеться на чверть фоут позаду інших. Квотербеки входять до атакувального складу команди, зазвичай вважаються лідерами і на нарадах у колі часто за ними залишаеться 
остаточне рішення про комбінацію, яку команда збирається розігрувати. У сучасній англійській мові цей термін використовуеться як діеслово та означає «керувати, координувати операцію: «Rev. J. Bryan Hehir quarterbacked the production of the Catholic bishops' pastoral» (Washington Post).

Як іменник «квотербек» може мати іронічне забарвлення, позначаючи «поціновувача або критика футболу, який вважае себе великим знавцем гри» (особливо у виразах «downtown quarterback», "grandstand quarterback»). Пізніше розвинулося значення «людина, яка сама не бере участі в чомусь, але аналізуе, дає поради, критикує на відстані або заднім числом; розумний заднім розумом». Це значення проявляеться у виразі «armchair quarterback», який обігруеться у пісні з такою ж назвою гурту «Ten Foor Pole»:

At work your mouth stays firmly shut

While your boss asks for advice

Later at the bar behind his back you criticize.

An armchair quarterback,

You'll never have to lose,

You'll never have to wipe the dog shit off your shoes,

An armchair quarterback.

У політищі використовуеться вираз «а star quarterback», який означає «найбільш ймовірний переможецы: «In 2012, the Republican Party selected Mitt Romney as their star quarterback to beat Barack Obama in the presidential election».

У футболі біля сильних гравців суперники часто ставлять двох своїх спортсменів, щоб перешкоджати їм здобувати очки. Така тактика називається «double teaming». Так само говорять, коли два політики нападають разом на свого колегу 3 іншого табору. Наприклад, заголовок із журналу «Time»: «The Clintons Double-Team Obama».

Набір різних технік, опис стратегій та їхніх варіацій фотболісти називають «playbook». Керівники політичних кампаній запозичили цей термін для назви своїх комплексних програм i різних тактик для перемоги на виборах: «Brett Kavanaugh deploys the Trump and Clinton playbook. When the Access Hollywood tape surfaced late in the 2016 presidential campaign, Donald Trump adopted the same playbook» $(B B C)$.

Висновки... Американський фрутбол - важлива складова американської свідомості, це гра за кожен сантиментр поля, це боротьба. На думку багатьох соціологів, політиків, журналістів і самих спортсменів, - це боротьба самої Америки. «Так само як захоплюють і втрачають метр поля, наша історія позначена моментами поступу i регресу. Але важливим є те, що ми повертаемося до метафоричної лінії 
центру, шикуємося і намагаємося, за словами нашої фоутбольної легенди Генка Стрема, доставити м'яч через поле. Всі разом, як одна команда» [7].

Метафора американського фрутболу стала частим образом у сучасній літературі, оскільки е виразником американських цінностей, таких як командна робота та індивідуалізм, демократія, динамічність. Крім того, фрутбольна термінологія поповнила лексичний запас англійської мови неологізмами, які використовуються як у популярній культурі (пісні), так і в бізнесі, політиці, газетних текстах. На нашу думку, тема американського фрутболу потребуе глибшого багатоаспектного вивчення, оскільки це один із важливих складників американської ідентичності, як культурної, так і мовної.

\section{Список використаних джерел і літератури:}

1. Вербицкая О. Ю. Культурная метафора «американский футбол» как инструмент понимания культурных ценностей американского общества. Magister Dixit. 2014. № 3 (15). С. 54-59.

2. Дмитрошкін Д. Е. Особливості утворення спортивних термінівкомпозитів. Нова фбілологія. 2010. № 42. С. 49-56.

3. Терпелец Ж. А. Футбольный дискурс: языковая вариативность и национальная специфика (на материале французского и английского языков). Филологические науки. Вопросы теории и практики. 2018. № 8 (86). Ч. 2. C. 388-394.

4. Alkhimovich A. Cultural Metaphors: American Football in IT-world. URL:https://www.linkedin.com/pulse/cultural-metaphors-american-football-itworld-anita-alkhimovich/ Дата звернення : 07.09.2018.

5. Bor C. Cultural Metaphor of the USA / Collins Bor. URL http://www.academia.edu/25401865/CULTURAL_METAPHOR_OF_THE_USA. Дата звернення : 01.10.2018.

6. Gannon M. Understanding Global Cultures: Metaphorical Journeys Through 28 Nations, Clusters of Nations, and Continents. Sage, 2004. 459 p.

7. Kerrigan M. Let's Keep Politics - and Kneeling - out of Football. URL https://www.charlotteobserver.com/opinion/op-ed/article171549417.html. Дата звернення : 21.09.2018.

8. Lahiri J. Lowland. A\&C Black, 2013. 352 p.

9. Mukherjee B. Desirable Daughters. Hyperion Books, 2002. 320 p.

10. Paul C. Seeing the Page like a Quarterback Sees the Field. URL: https://litreactor.com/columns/seeing-the-page-like-a-quarterback-sees-the-field Дата звернення : 14.09.2018.

\section{References:}

1. Verbitskaya O. Yu. Kulturnaya metafora «amerikanskiy futbol» kak instrument ponimaniya kulturnykh tsennostey amerikanskogo obshchestva / Olga Yurievna Verbitskaya // Magister Dixit. — 2014. — № 3 (15). — P. 54-59. 
2. Dmytroshkin D. E. Osoblyvosti utvorennia sportyvnykh terminivkompozytiv / Denys Eduardovych Dmytroshkin // Nova filolohiya. — 2010. — № 42. - P. 49-56.

3. Terpelets Zh. A. Futbolnyi diskurs: yazykovaya variativnost I natsionalnaya spetsifika (na materiale frantsuzskogo I angliiskogo yazykov) / Zhanna Alfredovna Terpelets // Filologicheskiye Nauki. Voprosy teorii I praktiki. — 2018. — № 8 (86) . - P. 2. - P. 388-394.

4. Alkhimovich A. Cultural Metaphors: American Football in IT-world / Anita Alkhimovich [електронний pecypc] // https://www.linkedin.com/pulse/cultural-metaphors-american-football-it-worldanita-alkhimovich/ - Дата звернення : 07.09.2018.

5. Bor C. Cultural Metaphor of the USA / Collins Bor [електронний ресурс] // http://www.academia.edu/25401865/CULTURAL_METAPHOR_OF_THE_USA — Дата звернення : 01.10.2018.

6. Gannon M. Understanding Global Cultures: Metaphorical Journeys Through 28 Nations, Clusters of Nations, and Continents / Martin Gannon. Sage, 2004. - $459 \mathrm{p}$.

7. Kerrigan M. Let's Keep Politics - and Kneeling - out of Football / Mile Kerrigan [електронний pecypc] //https://www.charlotteobserver.com/opinion/oped/article171549417.html — Дата звернення : 21.09.2018.

8. Lahiri J. Lowland / Jhumpa Lahiri. — A\&C Black, 2013. - 352 p.

9. Mukherjee B. Desirable Daughters / Bharati Mukherjee. - Hyperion Books, 2002. $-320 \mathrm{p}$.

10. Paul C. Seeing the Page like a Quarterback Sees the Field/ Christoph Paul [електронний ресурс] //https://litreactor.com/columns/seeing-the-page-like-aquarterback-sees-the-field — Дата звернення : 14.09.2018.

\section{Summary \\ Nataliia Bidasiuk, Nataliia Sobol American Football as a Cultural and Language Metaphor}

The article explains the notion "American football» and analyzes its metaphoric use in modern literature as a synonym to the word "American". Examples from fiction, lyrics, newspaper articles demonstrate how the English vocabulary has been enriched with other metaphorized football terms. It is emphasized that American football is an important component of American identity, both cultural and language.

Key words: American football, metaphor, identity, quarterback, neologism.

Дата надходження статті: «12» веерсня 2018 р.

Дата прийняття до друку: «28» вересня 2018 р. 